\title{
Crystallomorphology of Cassiterite and Its Practical Importance
}

\author{
I. Vdovina ${ }^{(\bowtie)}$ \\ Nizhny Novgorod Institute of Education Development, \\ Nizhny Novgorod, Russia \\ viann@inbox.ru
}

\begin{abstract}
The methods of applied mineralogy are used to assess the scale of the mineralization of tin occurrences and deposits. One of such methods is the crystallomorphological method for estimating the level of tin ore bodies developed by N.Z. Evzikova. According to the crystallomorphological features of cassiterite it allows one to estimate the possible depth of distribution of mineralization and its magnitude. Using the example of three studied tin-ore districts of the Far East the possibilities of using crystallomorphology of cassiterite to predict and evaluate the prospect of mineralization of both the ore region as a whole and individual ore occurrence at the exploration stage are shown.
\end{abstract}

Keywords: Applied mineralogy $\cdot$ Crystallomorphology •

Crystallomorphological method $\cdot$ Cassiterite $\cdot$ Scale of mineralization •

An assessment of prospects

\section{Introduction}

The task of screening ore occurrences has always been and remains one of the important tasks of the geological survey. One of the achievements of applied mineralogy in the history of its development is participation in metallogenic researches and the development of the theory of mineral deposits prediction. Among the tasks solved by the methods of applied mineralogy (in particular the search for crystallomorphology) there are tasks aimed at determining the scale of mineralization (its vertical extent and the magnitude of the erosion-denudation slice). The methods of the search crystal morphology are based on two important postulates: the ontogenic development of the mineral form and the doctrine of typomorphism. One of such methods is crystallomorphological method for estimating of tin ore occurrences developed by $\mathrm{N}$. Z. Evzikova on the example of tin deposits.

\section{Methods and Approaches}

Crystallomorphological method for evaluating of tin ore occurrences (Evzikova 1984) is based on the difference in the natural appearance of cassiterite crystals in different parts of the ore-bearing system as they move away from the source. The deeper parts of 
the ore bodies correspond to short-prismatic, isometric forms of cassiterite (I and II types), the higher-elongated forms of crystals (IV and V). The scale of the mineralization and the degree of its preservation reflect the crystallomorphological criteria: scoring represented by the statistical predominance of types IV and V and values from 50 to 200; degree of elongation of crystals (object's class) reflecting the completeness of the crystallomorphological evolution; the homogeneity of the morphology of cassiterite in different height sections of the ore object. The scoring factor is calculated by the formula $\mathrm{B}=[2(\mathrm{~V})+(\mathrm{IV})]-[2$ (I) $+(\mathrm{II})]$, where I, II, IV, V is the percentage of crystal morphological types in the sample.

The testing of this method at various times took place at tin ore deposits of the Far East where for the first time this method was used to evaluate the prospects for tin ore mineralization in exploration. The author has researched the crystallomorphological features of cassiterite from the ore manifestations of three Far Eastern tin ore regions (the Komsomolsk, Badzhal, Yam-Alin regions) in order to obtain a crystallomorphological estimate of the prospect of their mineralization.

\section{Results and Discussion}

Ore districts are located within the Khingan-Okhotsk volcano-plutonic belt and the same-name tin-bearing region. The Khingan-Okhotsk volcano-plutonic belt represents a vast magmatic area of the northeast strike superimposed on a heterogeneous foundation formed in the atmosphere of the transform continental margin. The Badzhal region is located in the junction zone of ancient Archean-Proterozoic cratons and Mesozoic accretionary folded belts and is characterized by the presence of a Cretaceous volcano-tectonic formation in the central part of the granitoid batholith.

Komsomolsk and Yam-Alin regions are located in accretionary folded systems spatially coincides with the eponymous volcanic zone (Rodionov 2005).

The Komsomolsk Ore Region. Several hundreds of ore mineralization zones, mainly cassiterite-silicate formation, have been established within the Komsomolsk ore region. By the beginning of 90 s of last century crystallomorphological researches covered about 40 manifestations of tin mineralization in which a fairly representative number of samples were analyzed. 25 ore manifestations of this number were evaluated at deep horizons in the process of prospecting and evaluation (14) or exploration which made it possible to determine the reliability of forecasts obtained earlier by the crystallomorphological method.

When sorting out 25 ore occurrences by crystallomorphological method 11 mineralization zones received a positive forecast. Subsequent testing at the exploration stage confirmed this forecast for 6 ore occurrences. In five positively evaluated by the subsequent preliminary exploration the forecast was not confirmed.

Among the ore occurrences that received a negative assessment on the depth 10 objects were studied. The convergence of the results in these cases turned out to be higher. A negative forecast was confirmed by 8 occurrences. And only in two zones contrary to expectations industrial ores have been established. 
The Badzhal Ore Region. The crystallomorphological researching of cassiterite from the ore occurrences of the Badzhal ore district began with the first explorations in the middle of 70s of the last century (Vdovina 2005).

In the process of research at the exploratory stage the cassiterite ore occurrences of the "Badzhal axis" structure were studied. Crystallomorphological criteria indicated a high level of slice and insignificant prospects for ore occurrences. No detailed work has been done.

The Pravourmiyskoe deposit was the most studied in details. The morphology of cassiterite crystals of this deposit was researched at all stages of prospecting and exploration (Vdovina 1987, 2008).

At the first stage of work the crystallomorphological mapping was carried out on surface mine workings. Evaluation of the mineralization's prospect was as follows:

- the level of the denudation slice is high enough;

- the gradient of the vertical crystallomorphological variability is large; the deposit is characterized by the proximity of the upper and lower boundaries of mineralization;

- the estimated length of the mineralization to the depth is $200-220 \mathrm{~m}$;

- the morphology of the crystals suggests a large length of mineralization to the depth and the occurence of industrial ores in the middle part of the deposit.

Material was obtained from the deep horizons of the deposit in the detailed exploration. The results of the crystallomorphological analysis of cassiterite of the Pravourmiyskoe deposit were confirmed by the results of exploration. The length of the mineralization to a depth was no more than $250 \mathrm{~m}$. The level of the denudation slice is really high. In addition the results of cassiterite of the Pravourmiyskoye deposit's crystallomorphological features researching confirmed the regularity of the spatial and temporal distribution of the morphological types of cassiterite. The same sequence of the cassiterite crystals changing from type I to type $\mathrm{V}$ was established at the stockwork type of the cassiterite-quartz formation. The deposit is currently being exploited.

About a dozen have been studied within the Verkhnebadzhalsky ore cluster. Most detailed and from the surface and from the depth Blizhnee deposit has been explored (Vdovina 2011).

The Blizhnee Deposit. Cassiterite is of a short-prismatic almost isometric habit, IV and less than V type, the score is 92-130. According to the crystallomorphological features the prospect of mineralization to a depth is small. Exploration data did not confirm the depth of the deposit.

The Talidzhak mine is the most perspective one. Cassiterite is predominantly IV and $\mathrm{V}$ types, of medium degree of elongation, the scaling varies within 100-200. The gradient of crystal morphological variability is weak. Ore occurrences are characterized as poorly eroded. The vertical extent of mineralization is assumed to be $500 \mathrm{~m}$. The detailed exploration has not been carried out.

The Yam-Alin Ore Region. Ore occurrences were researched only at the exploration stage. There is the Sorukan deposit. Cassiterite is situated in the zones of quartz-chlorite 
composition in the form of scattered and nested impregnation and quartz-cassiterite lenses and veinlets. Pyramid-prismatic crystals of type IV of crystallomorphological type prevail in their composition, crystals of type $\mathrm{V}$ are found in a small amount. There are a lot of prismatic fragments of crystals of very different lengths including conical. All type IV crystals are characterized by a moderate and strong degree of elongation, a zonal structure; growth zones fix the development of cassiterite in types II-IV. The deposit's class development is 4 . The deposit is poorly eroded and perspective on depth.

The ore occurrences of the Shiroky, Exan and Bastion sections from the different ones are of interest. Cassiterite is very small, almost colorless, slightly yellowish, often observed in star splices and aggregates. It is presented by IV and V crystallomorphological types with a predominance of type V. The crystals are characterized by short heads (dull pyramid), moderate and strong degree of elongation. The crystals are transparent, zonal; the observed growth phantoms show their development in type IV and III. Often there are simple articulated twins. The presence of cassiterite of different physical and crystallomorphological properties gives the right to assume the development of tin mineralization in several stages. In general the district is prospective, poorly eroded.

According to the results of the crystallomorphological method the most promising sections include the majority of the studied sections.

\section{Conclusions}

The author believes that the use of crystallomorphological analysis to determine the denudation slice, the extent of mineralization to the depth and generally for the industrial evaluation of tin mineralization is appropriate at the exploration stage. But the credibility and reliability of the assessment will increase if it is used in combination with others, in particular, at the first stage with structural and morphostructural (Vdovina 2008), and at later ones with more "direct" mineralogical, geochemical and other researches.

\section{References}

Evzikova NZ (1984) Prospecting cristal morphology, Moscow

Rodionov SM (2005) Metallogeny of tin of East of Russia, Moscow

Vdovina IA (1987) Crystallomorphology of cassiterite as one of the criteria for industrial evaluation of the tin ore deposit in notes all-union. Mineral Soc Part XVI, I:60-65

Vdovina IA (2005) Crystallomorphological features of cassiterite occurrences in the Badzhal ore region. Nat Geogr Res, Komsomolsk-na-Amure, pp 4-13

Vdovina IA (2008) Morphostructural-crystallomorphological evaluation of the prospect of mineralization (on the example of the Badzhal tin ore region) in Fedorov session 2008. Thesises of international scientific conferences, Saint-Petersburg, pp 246-249 
Vdovina IA (2011) About the crystallomorphology of cassiterite. In: X international conference «New ideas in the Earth sciences». Reports in 3 volume. Russian State Geological Exploration University, Moscow, vol 1, pp 107-108

Open Access This chapter is licensed under the terms of the Creative Commons Attribution 4.0 International License (http://creativecommons.org/licenses/by/4.0/), which permits use, sharing, adaptation, distribution and reproduction in any medium or format, as long as you give appropriate credit to the original author(s) and the source, provide a link to the Creative Commons license and indicate if changes were made.

The images or other third party material in this chapter are included in the chapter's Creative Commons license, unless indicated otherwise in a credit line to the material. If material is not included in the chapter's Creative Commons license and your intended use is not permitted by statutory regulation or exceeds the permitted use, you will need to obtain permission directly from the copyright holder. 